\title{
Isolation, identification and selection of lactic acid bacteria cultures for cheesemaking
}

\author{
Morsi El Soda, N. Ahmed, N. Omran, G. Osman and A. Morsi \\ Department of Dairy Science and Technology, \\ Faculty of Agriculture, Alexandria University \\ Alexandria, Egypt
}

\begin{abstract}
Lactic Acid Bacteria (LAB), which are considered to be the most useful microorganisms to society, are involved in the manufacture of thousands of fermented foods. They are also beneficial in flavoring foods, inhibiting pathogenic as well as spoilage bacteria in these products. A total of 2000 isolates of LAB were obtained from traditional Egyptian dairy products (different types of raw milk, ras, domiatti and kareish cheese, mish, cream, butter and fermented milk such as laban, rayeb and zabady) obtained from different regions in Egypt. The pre-identification tests were performed according to the morphological characteristics: catalase test, growth at $10^{\circ} \mathrm{C}$ and $45^{\circ} \mathrm{C}$, growth in the presence of $6.5 \% \mathrm{NaCl}$ and $\mathrm{Co} 2$ production. The isolates were subjected to phenotypic and cell wall protein characterization analyses. Phenotypically, 1006 strains were identified using API 50 CHL and API 20 Strep (Apparatus and procedure of identification). The SDS-PAGE technique (Sodium dodycyl sulfate) of whole cell protein was evaluated as an advanced tool for the identification of LAB. Therefore protein fingerprints were registered for 514 strains and compared to a large number of LAB reference strains stored in database format. The SDS-PAGE technique confirmed $94 \%$ of the API identification results. The identified strains were tested for acidifying activity, autolytic and aminopeptidase properties, antagonistic activities and polysaccharides production.

Selected cultures where then evaluated as starter or adjunct cultures for Ras and Domiatti cheese production in the cheese research laboratory. Higher cheese flavor scores were consistently obtained in Ras cheese made with cultures showing high peptidase and esterase activity and a high rate of autolysis. Development of free amino acids and free fatty acids in Ras cheese were always higher when compared to the cheese made using other starters.
\end{abstract}

Key words: LAB (Lactic Acid Bacteria) - Free amino acids - Free fatty acids - SDS-PAGE technique - API technique.

\footnotetext{
عزل ولنتخلبسلات بكتربا حمض اللكتيك المستخمةف صناعة الجبن

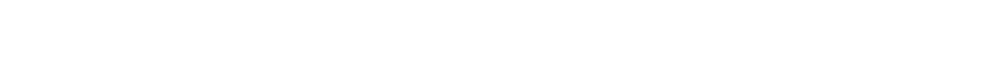




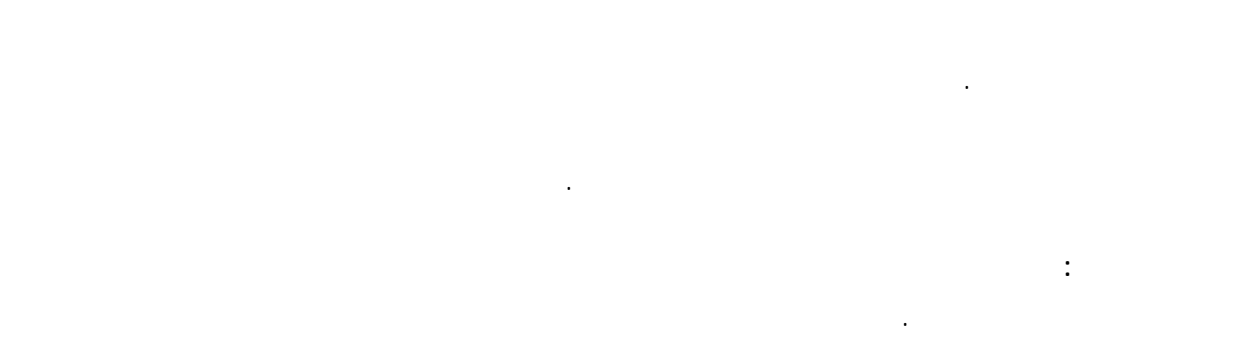

\section{Introduction}

Isolation and screening of microorganisms from naturally occurring processes have always been the most powerful means for obtaining useful cultures for scientific and commercial purposes. This is certainly true for lactic acid bacteria (LAB), which play an important role in a large number of various traditional food fermentations. Among these traditional processes, cheese and fermented milk are known to be essentially fermented by LAB, although often a functional secondary flora develops. Some properties of LAB such as flavour and texture formation are especially important to the food and feed industries because of their applicability for a large variety of products.

The dairy industry uses well-defined single strain and multiple strain starter cultures to obtain dairy products of high and constant quality. Therefore, a continuous need exists for the isolation of new strains with superior natural qualities. A high proportion of the cheese and fermented milks produced in Egypt are manufactured in the rural areas. In such products where no starter are added, fermentation occurs as a result of the wild flora present in the surrounding environment. The wild lactic acid bacterial flora represents a natural reservoir for cultures that were not exposed to any industrial selection.

Some interesting characteristics of these microorganisms are their ability to produce acid at a high and predictable rate, which is essential in cheese starter strains (Stadhouders, 1974，1986; Sandine, 1985; Farrow, 1980).

The proteolytic activity exerted by most LAB is not only a prerequisite for growth, but also affects product texture and flavour, especially in dairy products (Law and Kolstad, 1983; Thomas and Pritchard, 1987). Proteolytic activity encompasses proteinases that degrade proteins, such as caseins, into relatively large protein fragments, and peptidases that break down protein fragments into small peptides and free amino acids. The total proteolytic activity consists of a complex mixture of a proteinase and a number of peptidases (Kamaly and Marth, 1989; Olsen, 1990)

Certain strains of LAB are able to synthesize exopolysaccharides (EPS) that are secreted into their environment, such as milk (Cerning, 1990; Ricciardi and Clementi, 2000; Sikkema and Oba, 1998). In particular for the production of yoghurt, drinking yoghurt, cheese, fermented cream and milk based desserts, EPS producing LAB are very important (Cerning, 1995; Crescenzi, 1995). EPS contribute to the texture, mouth-feel, and taste perception and stability of the final product.

The ability of LAB to produce and excrete compounds with antimicrobial activity, such as bacteriocins, is well known (Geis et al., 1983; Klaenhammer, 1988). Bacteriocins are relatively small peptides, sensitive to specific proteolytic enzymes, can be heat stable and have antimicrobial (either bacteriocidal or bacteriostatic) activity 
against closely related, or in some cases a wide spectrum of microorganisms including foodborne pathogens such as Listeria monocytogenes and some Clostridia. This makes bacteriocin producers particularly for potential use in food preservation (Spelhaug and Harlander, 1989; Delves-Broughton, 1990; Marugg, 1991).

The aim of this study is to improve cheesemaking in Egypt through a selection of bacterial cultures from our environment in order to reproduce the characteristic flavour and texture of our endogenous products.

\section{Materials and Methods}

Isolation of LAB strains

The samples were collected from raw milk and traditional Egyptian dairy products such as Ras, Domiatti and Kareish cheese, mish, cream, butter, Zabady and Laban Rayeb.

The milk samples were incubated at $30^{\circ} \mathrm{C} ; 37^{\circ} \mathrm{C} ; 42^{\circ} \mathrm{C}$, while the cheeses, fermented milk, cream and butter samples were cultured in sterilized reconstituted skim milk before incubation until coagulation. Coagulated samples were then streaked on M17 (Biolife Italy), MRS (De Man et al., 1960); Rogosa (Difco, USA); ST and SF agar media. Samples streaked on MRS and Rogosa agar, were incubated under anaerobic condition using the gas pak system (GENER box anae indicator Biomerieux) at $30^{\circ} \mathrm{C}, 37^{\circ} \mathrm{C}$ and $42^{\circ} \mathrm{C}$ for $48 \mathrm{~h}$. For the isolation of the strains the following media were used: M17 for Lactococcus and Enterococcus strains, M17 + Vitamin for Streptococcus thermophilus and MRS for Lactobacillus, Pediococcus, and Leuconostoc. The cultures were streaked on suitable media for their purification. The purified strains were stored at $-20^{\circ} \mathrm{C}$ in sterile reconstituted skim milk $(12.5 \% \mathrm{~W} / \mathrm{V})$ supplemented with $15 \%$ glycerol.

\section{Identification of LAB strains}

Preliminary tests

More than 2000 cultures were assigned to genus level initially by morphology and simple physiological tests following the criteria of Sharpe (1979) using morphological, phenotypic and biochemical methods. They were examined microscopically for Gram staining and catalase production (Harigon and McCane, 1976). In addition, all strains were tested for growth at $10^{\circ} \mathrm{C}$ for 10 days, $45^{\circ} \mathrm{C}$ for $48 \mathrm{~h}$, and $\mathrm{CO}_{2}$ production from glucose. For cocci strains, growth on SF broth medium and in the presence of $6.5 \% \mathrm{NaCl}$ were also considered. The cultures were classified as stated below:

Gram positive, catalase-negative rods, which grew at $45^{\circ} \mathrm{C}$ and not at $10^{\circ} \mathrm{C}$, were considered as thermophilic lactobacilli, while those that didn't grow at $45^{\circ} \mathrm{C}$ and grew at $10^{\circ} \mathrm{C}$ were considered as mesophilic lactobacilli. Homofermentative, Gram positive, catalase negative cocci, which grew at $10^{\circ} \mathrm{C}$ but not at $45^{\circ} \mathrm{C}$ and $6.5 \%(\mathrm{w} / \mathrm{v})$ $\mathrm{NaCl}$, were considered mesophilic lactococci. Homofermentative, Grampositive, catalase-negative cocci, which grew at $45^{\circ} \mathrm{C}$, but not at $10^{\circ} \mathrm{C}$ and $6.5 \% \mathrm{NaCl}$, were considered as thermophilic cocci, while those which grew at $45^{\circ} \mathrm{C}, 10^{\circ} \mathrm{C}$ and $6.5 \%$ $\mathrm{NaCl}$, were considered as enterococci.

\section{API system}

The API 50CH system (Biomerieux, Marcy l'Etoile France) was used for the identification of lactobacilli, lactococci, Leuconostoc, Pediococcus, and S. thermophilus strains while API 20 STREP 
(Biomerieux, Marcy 1'Etoile France) was used for the enzymatic and carbohydrate fermentation patterns of enterococci strains. The API system was performed according to the manufacturer's instructions. Interpretations of the fermentation profiles were facilitated by systematically comparing all results obtained for the isolates studied with information from the computer-aided database APILAB Plus V.3.2.2. in which the identification of a microorganism is accompanied by the following information: (i) The percentage of identification (\%id) is an estimate of how closely the profile corresponds to the taxon relative to all the other taxa in the database. (ii) The T-index represents an estimate of how closely the profile corresponds to the most typical set of reactions for each taxon. Its value varies between 0 and 1, and is inversely proportional to the number of atypical tests.

(iii) Comments on the quality of identification derived from the $\%$ id and the T-index of the selected taxon (excellent identification $\%$ id $>99.9$ and $\mathrm{T}>0.75$ ).

\section{SDS-PAGE of the whole-cell proteins}

Five hundred and fourteen from 1006 strains previously identified from their phenotypic characteristics were submitted to SDS-PAGE of the whole-cell proteins to confirm the API results. Lactobacilli, Leuconostoc, Pediococcus, and S. thermophilus strains were inoculated with $2 \%$ of $24 \mathrm{~h}$ overnight culture and the cells were collected after $16 \mathrm{~h}$ incubation by centrifugation $\left(7000 \mathrm{~g}, 10 \mathrm{~min}, 4^{\circ} \mathrm{C}\right)$. The cell pellet was washed twice with sodium phosphate buffer $(0.01 \mathrm{M} ; \mathrm{pH} 7.3)$ containing $0.08 \% \mathrm{NaCl}$. On the other hand, lactococci and enterococci strains were plated on the M17 agar and incubated for 48h. Bacterial cells were collected and suspended in eppendorf tubes containing $1 \mathrm{ml}$ phosphate buffer $(0.01 \mathrm{M} ; \mathrm{pH} 7.3)$. After centrifugation, the resulting pellet was washed with the same buffer. The cell pellet was resuspended in $0.9 \mathrm{ml}$ sample treatment buffer $(0.062 \mathrm{M}$ Tris $\mathrm{HCl}$ buffer containing $5 \% \mathrm{~V} / \mathrm{V}$ mercaptoethanol and $10 \%$ glycerol; $\mathrm{pH} 6.8$ ). The ice cooled cell suspension was then treated with an Ultrasonic XL 2020 apparatus using a needle probe tip and mixed by vortex. $0.1 \mathrm{ml}$ of SDS (20\%) was added in this suspension. The mixture was heated at $95^{\circ} \mathrm{C}$ for $10 \mathrm{~min}$ and cooled in ice. The whole cell protein extracts were obtained by centrifugation $\left(7000 \mathrm{~g}, 10 \mathrm{~min}, 4^{\circ} \mathrm{C}\right)$ of the suspension. The 1D electrophoresis of these protein extracts was run as previously described by Pot et al., (1994). Registration of the protein electrophoretic patterns, normalization of densitometric traces, grouping of strains by the Pearson product moment correlation coefficient (r) and UPGMA (Unweighted Pair Group Method Using Averages Linkages) cluster analysis were performed by the techniques described by Pot et al., (1994) using the software package Gelcompar (Applied Maths, Belgium; 4.0). Identification of the isolates was performed by comparison of their protein patterns to the fingerprints of reference strains of $\mathrm{LAB}$ in the database of the Laboratory of Microbial Biochemistry of the University of Alexandria obtained from different culture collections. The reproducibility of the electrophoretic system was investigated by inclusion of reference bacterial protein extracts in each slab gel as well as repetition of the electrophoretic runs or the duplication of the injection of the same samples. 


\section{Performance tests}

Acidifying activity

Seventy $\mathrm{ml}$ of the suitable broth media were inoculated with $10 \% 24 \mathrm{~h}$ overnight, activated subcultures of LAB strains. The growth of cultures in broth media was monitored at $650 \mathrm{~nm}$ using a spectrophotometer (Pharmacia LKB. NOVASPEC II) during 6h. At the early stationary growth phase, bacterial cells were harvested by centrifugation of $30 \mathrm{ml}$ of the culture $\left(4000 \mathrm{~g}, 10 \mathrm{~min}, 4^{\circ} \mathrm{C}\right)$. The cell pellet was washed twice with $10 \mathrm{ml}$ ringer solution. The resulting cell pellet was suspended in $35 \mathrm{ml}$ sterile reconstituted skim milk $(12.5 \%$ W/V) supplemented with sucrose (7\%), $5 \mathrm{ml}$ of this mixture was stored in ice at $4{ }^{\circ} \mathrm{C}$ for $24 \mathrm{~h}$. Sterile reconstituted skim milk $(12.5 \%$ $\mathrm{W} / \mathrm{V})$ was inoculated with $2 \%$ of the cell pellet suspended in milk-sucrose. The change of $\mathrm{pH}$ was determined using a $\mathrm{pH}$ meter (Microcomputer $\mathrm{pH}$-vision, model 05669-20) during six hours incubation at the suitable temperature.

\section{Aminopeptidase activity (AP)}

Intracellular and extracellular
aminopeptidase activities
measured according to the slightly modified procedure described by Miozzari et al., (1978) using L-Leucine para nitroanilide (Leu-pNA) as substrate (El Soda and Desmazeaud, 1982). In fact, cells of different cultures were harvested in the early stationary growth phase by centrifugation at $7000 \mathrm{~g}$ for $10 \mathrm{~min}$, at $4^{\circ} \mathrm{C}$. The cell pellet was washed twice and the resulting pellet was then resuspended in $1 / 10$ of the initial volume of the growth medium.

A portion of cell suspension was added to $50 \mathrm{ml}$ of potassium phosphate buffer $(\mathrm{pH} 7$, $0.01 \mathrm{M}$ ) to obtain the cell optical density of
0.9 to 1 at $650 \mathrm{~nm}$. The resulting suspension was divided in two portions and each portion was centrifuged for $10 \mathrm{~min}$ at $7000 \mathrm{~g}$ at $4^{\circ} \mathrm{C}$. After centrifugation, the cell pellets were weighed and resuspended in the potassium phosphate buffer to obtain a final concentration of cell $(100 \mathrm{mg}$ of wet cell pellet $/ \mathrm{ml}$ buffer). To extract intracellular enzyme, one of the portions was treated with toluene $(1000 \mathrm{mg}$ of wet cell pellet $/ \mathrm{ml}$ toluene). After mixing by vortex, these suspensions were frozen at $-20^{\circ} \mathrm{C}$ for $24 \mathrm{~h}$. The frozen cell suspensions were thawed at room temperature and centrifuged at $7000 \mathrm{~g}$ for $20 \mathrm{~min}$ at $4^{\circ} \mathrm{C}$. The free cell supernatant of each portion was collected and used as enzyme extract.

The aminopeptidase activity was then tested using $50 \mu \mathrm{l}$ of Leu-pNA (Biomedicals, INC.) $\quad(6 \mathrm{mg} / \mathrm{ml}$ methanol); $1.8 \mathrm{ml}$ of potassium phosphate buffer $(\mathrm{pH} 7 ; 0.01 \mathrm{M})$ and $0.2 \mathrm{ml}$ of enzyme extract. The mixture was incubated at a suitable temperature. The variation of the optical density was measured at $410 \mathrm{~nm}$ after the changing of the colour with a spectrophotometer (Pharmacia 1KB, NOVASPEC II). In these experimental conditions, the enzyme activity corresponding to O.D.650nm (0.9-1) of cell suspension was expressed as the variation of the optical density at $410 \mathrm{~nm}$ per minute per milliliter of enzyme extract.

\section{Measurement of the rate of autolysis}

The rate of cell autolysis was measured according to the method of Thiboutot et al., (1995) which could be summarized as follows: cells of different cultures were harvested by centrifugation and washed twice. The resulting bacterial pellet was then resuspended in $1 / 10$ of the initial volume of the growth medium, and then frozen at $20^{\circ} \mathrm{C}$. The frozen cell suspension was thawed at $37^{\circ} \mathrm{C}$. A portion of cell suspension 
was added to potassium phosphate buffer (pH 5.5, 0.01M) containing sodium chloride to obtain an optical density of 0.9 to 1 at $650 \mathrm{~nm}$. This suspension was then incubated at $40^{\circ} \mathrm{C}$ and cell lysis was followed by absorbance measurement at $650 \mathrm{~nm}$ on a spectrophotometer (Pharmacia LKB. NOVASPEC II) after $6 \mathrm{~h}, 24 \mathrm{~h}$ and $48 \mathrm{~h}$. Cell autolysis was characterized using the percentage of cell lysis as defined by Boutrou et al., (1998).

\section{Exopolysaccharides (EPS) production}

The screening of EPS production was limited to the strains showing weak pellet after centrifugation. The procedure used consisted of revealing the presence of diffuse capsules surrounding bacteria cells. The strain producing capsules were also tested for slime formation. For these purposes, on a clean slide, a loop of broth culture was mixed with a drop of India ink, covered with a cover glass and examined under a microscope with phase contrast (ZEISS Microscope, West Germany) (Prescott, et al., 1996). For slime production, strains were streaked on the suitable media and incubated at the optimum growth temperature for $24 \mathrm{~h}$. Ropiness of colonies on agar surfaces was tested with a loop to observe the formation of slimy filaments.

\section{Antagonistic effects}

The LAB cultures were tested for antagonistic activity against each other as follows: The overnight cultures were spotted onto agar plates. The plates were incubated for $48 \mathrm{~h}$ at suitable temperature to allow producer colonies to develop. Then a suitable soft agar medium was inoculated with the indicator strain and poured onto the surface of the plate showing the colonies of the producer strain. After $18 \mathrm{~h}$ of incubation under anaerobic conditions, at a suitable temperature, the plates were checked for zones of inhibition surrounding the producer strain colonies (Geis et al., 1983).

Enhancement cheese flavour using different starter / adjunct combinations Cell cultivation and freeze shocking

For the cultivation of cells, MRS broth was inoculated with an active culture of the adjunct culture in the same medium. At the early stationary phase, cells were harvested by centrifugation at $4000 \mathrm{rpm}$ for $10 \mathrm{~min}$ at $4^{\circ} \mathrm{C}$. The pellet was washed twice with 0.01 Mpotassium phosphate buffer, $\mathrm{pH} .7$ and resuspended in the same buffer. The cell suspension was frozen at $-20^{\circ} \mathrm{C}$ for $24 \mathrm{~h}$. and thawed in a water bath at $40^{\circ} \mathrm{C}$ prior to use.

Preparation of cheese curd for use in cheesemaking

Many experiments were performed using commercial starters and selected adjunct cultures isolated from Egyptian dairy products to make Ras cheese. These mixtures were used in order to select the best starter for making-cheese. Cheeses were manufactured from standardized pasteurized milk in $11 \mathrm{~L}$ vats. A commercial starter culture in addition to selected and commercial adjuncts were added to milk at $32^{\circ} \mathrm{C}$. Calcium chloride was added before renneting with a chymosin preparation $(2 \%$ w/v, Chymax, Chr.Hansen's Lab). The coagulum was cut and cooked to $45^{\circ} \mathrm{C}$ for $105 \mathrm{~min}$. After whey drainage, the curd was molded, pressed over-night and ripened at $15-20^{\circ} \mathrm{C}$. An automatic cheese pilot plant facility was used which provided conditions similar to those used on the commercial scale. 
Emir. J. Agric. Sci. 2003. 15 (2): 51-71

http://www.cfs.uaeu.ac.ae/research/ejas.html

Physico - Chemical analysis of cheese

Samples of the cheese were analyzed for titrable acidity as recommended by the Association of Official Analytical Chemists (A.O.A.C) (1960), pH determination was measured using a glass electrode (Cole Parmer LCD model 5994-10), fat content was determined by the Gerber method as described by Ling, (1952), moisture was determined by using the moisture analyzer (Mettler Toledo Model HR73), total protein was determined according to the A.O.A.C., and salt content was determined using Chloride Meter Model PCLM3, Jenway, England.

Proteolysis in cheese was assessed by measuring the concentration of free amino groups by the Cd-ninhydrin method as described by Folkertsma and Fox, (1991). Free fatty acids (FFA) were determined according to the method described by Godinho and Fox (1981).

\section{Results and Discussion}

Identification of various lactic cultures

More than 2000 cultures were isolated from various sources. The first screening revealed the presence of 1451 cocci and 656 rods which were further identified using classical techniques and allocated to the following groups (Table 1).

From all isolated strains, 1006 strains were identified using the API system. Nine hundred and seventy nine strains were satisfactorily identified as shown in Table 2; while for the remaining 27 strains a doubtful identification was obtained. Bill et al., (1992) and Klinger (1992) indicated that some commercial identification systems often yield good results regarding genus identification but they were not fully adequate at the species level.

Table 1. Identification of isolated strains using classical techniques.

\begin{tabular}{lc}
\hline \multicolumn{1}{c}{ Genus } & Number \\
\hline Lactococcus & $237(11 \%)$ \\
Enterococcus & $1021(48 \%)$ \\
Streptococcus thermophilus & $170(8 \%)$ \\
Pediococcus & $5(0.2 \%)$ \\
$\begin{array}{l}\text { Leuconostoc } \\
\text { A. Obligately Homofermentative }\end{array}$ & $18(0.8 \%)$ \\
$\quad$ lactobacilli & $130(7 \%)$ \\
B. Facultatively Heterofermentative & $278(13 \%)$ \\
$\quad$ lactobacilli & \\
C. Obligately Heterofermentative & $248(12 \%)$ \\
$\quad$ lactobacilli & \\
\hline
\end{tabular}

Table 2 reveals the presence of relatively high number of enterococci in the Egyptian dairy products, $32 \%$ of the identified cultures were Enterococcus faecium. They produce acid from mannitol and arabinose (DurluOzkaya et al., 2001). Ninety three percent of identified Lactococcus strains were L. lactis subsp. lactis, they hydrolyse esculin and formed acid from lactose, maltose, salicine and ribose but acid production from mannitol, sucrose and D-xylose was strain dependent (Sharpe, 1979; Schleifer et al., 1985; Balows et al., 1991). The two $S$. thermophilus strains ferment lactose and sucrose while one of them forms acid from glucose.

Identified Lactobacillus strains were classified into 3 groups (Kandler and Weiss, 1986) as shown in Table 2. L. delbrueckii subsp. lactis was the predominant species in group A. L. plantarum and L. fermentum strains represented the highest numbers of lactobacilli in group B and group C, respectively. 
Table 2. API results for the isolated strains.

\begin{tabular}{|c|c|}
\hline $\begin{array}{r}\text { Species identified using API system } \\
\end{array}$ & Number \\
\hline Lactococcus lactis subsp. lactis & $172(17.5 \%)$ \\
\hline Lactococcus lactis subsp. cremoris & $13(1.3 \%)$ \\
\hline Streptococcus hermophilus & $2(0.2 \%)$ \\
\hline Leuconostoc mesentroids subsp mesentroids / dextranicum & $14(1.4 \%)$ \\
\hline Leuconostoc lactis & $2(0.2 \%)$ \\
\hline Pediococcus pentosaceus & $2(0.2 \%)$ \\
\hline Enterococcus faecium & $312(31.8 \%)$ \\
\hline Enterococcus durans & $72(7.4 \%)$ \\
\hline Enterococcus faecalis & $27(2.8 \%)$ \\
\hline Enterococcus avium & $5(0.5 \%)$ \\
\hline Enterococcus casseliflavus & $8(0.8 \%)$ \\
\hline \multicolumn{2}{|l|}{ Obligately Homofermentative lactobacilli (G.A) } \\
\hline Lactobacillus delbrueckii subsp bulgaricus & $30(3.2 \%)$ \\
\hline Lactobacillus delbrueckii subsp lactis & $58(5.6 \%)$ \\
\hline Lactobacillus delbrueckii subsp. delbrueckii & $2(0.2 \%)$ \\
\hline Lactobacillus helveticus & $6(0.6 \%)$ \\
\hline Lactobacillus acidophilus & $4(0.4 \%)$ \\
\hline Lactobacillus salivarius & $5(0.5 \%)$ \\
\hline \multicolumn{2}{|l|}{ Facultatively Heterofermentative lactobacilli (G.B) } \\
\hline Lactobacillus rhamnosus & $47(4.8 \%)$ \\
\hline Lactobacillus paracasei subsp. paracasei & $20(2.5 \%)$ \\
\hline Lactobacillus plantarum & $70(7.2 \%)$ \\
\hline Lactobacillus pentosus & $6(0.6 \%)$ \\
\hline Lactobacillus curvatus & $3(0.3 \%)$ \\
\hline \multicolumn{2}{|l|}{ Obligately Heterofermentative lactobacilli (G.C) } \\
\hline Lactobacillus fermentum & $88(8.9 \%)$ \\
\hline Lactobacillus brevis & $7(0.7 \%)$ \\
\hline Lactobacillus collinoides & $1(0.1 \%)$ \\
\hline Lactobacillus fructivorans & $1(0.1 \%)$ \\
\hline Lactobacillus viridescens & $1(0.1 \%)$ \\
\hline Lactobacillus cellobiosus & $1(0.1 \%)$ \\
\hline
\end{tabular}


Emir. J. Agric. Sci. 2003. 15 (2): 51-71

http://www.cfs.uaeu.ac.ae/research/ejas.html
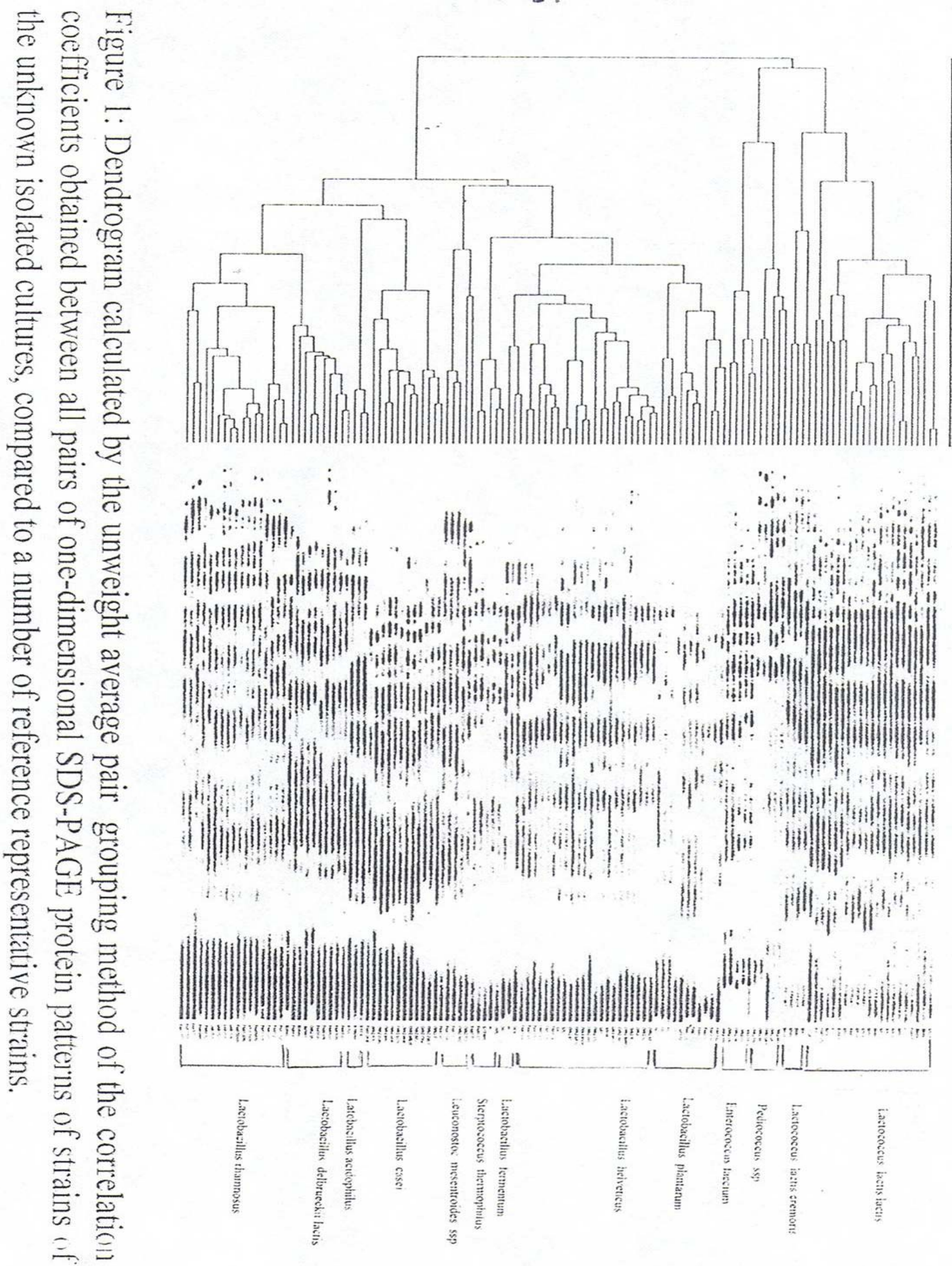

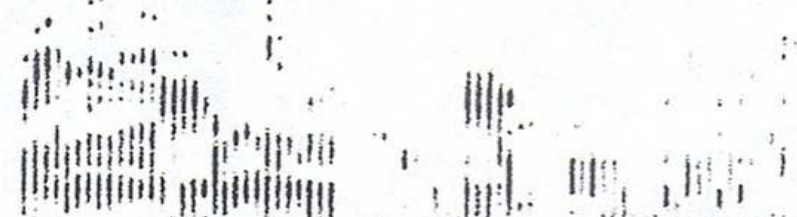

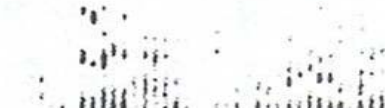

$\therefore$ uIIII (i)

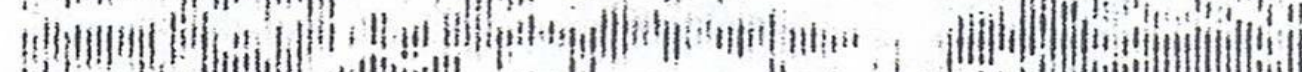
(i)

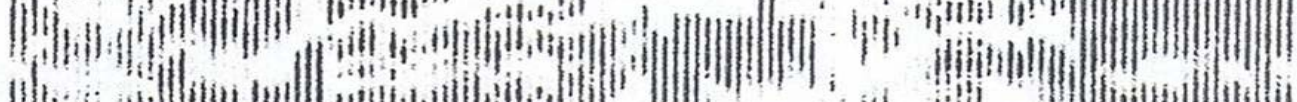
IIp IIII)

I.t. If

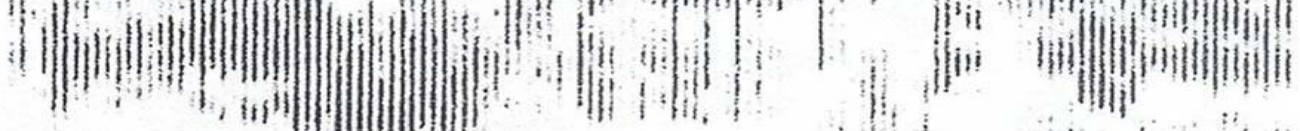
$\therefore+i$ t III) iflat"
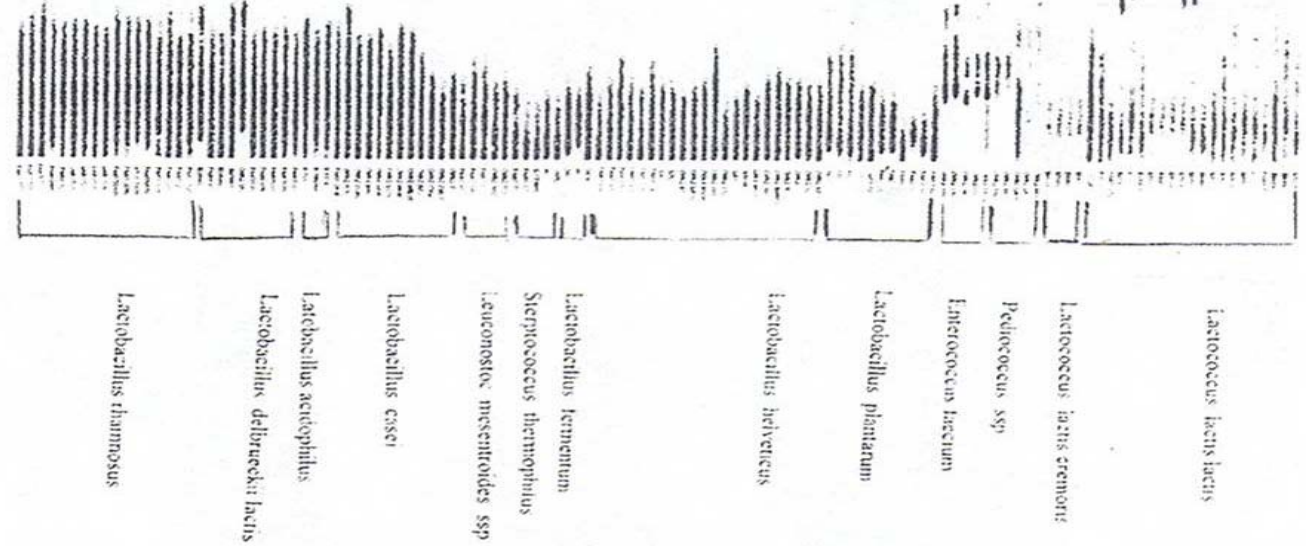

IL 1 is in || || || 
Using the gel compar software package (version 4), 514 protein patterns were compared with protein fingerprints of reference strains including the genera Lactobacillus, Pediococcus, Enterococcus, Lactococcus, and Leuconostoc, and Streptococcus thermophilus (Pot and Janssens, 1993). The resulting dendrogram is shown in Figure 1. According to the SDSPAGE results, the phenotypic characterization was confirmed for all $L$. lactis subsp. lactis and $S$. thermophilus strains. On the other hand, there were differences between the API system and SDS-PAGE technique results for some lactobacilli. Cultures identified as $L$. delbrueckii subsp. lactis or L. helveticus using the API system were classified by SDS-PAGE as L. helveticus (similarity 70\%). Seven strains phenotypically characterized as $L$. delbrueckii subsp. lactis or $L$. helveticus were identified by the SDSPAGE technique as L. delbrueckii subsp. lactis. The results of SDS-PAGE technique, confirmed $94 \%$ of the API results.

\section{Selection of the identified cultures.}

In this study, all the cultures that were satisfactorily identified were further selected according to technological criteria.

\section{Acidifying activity}

The obtained results revealed that the acidifying activity of Lactococcus strains was significantly higher than the activity of the other species. Figure 2 shows a typical example of three cultures with different acidifying rates. The obtained results (not shown) revealed that none of the Enterococcus strains can be characterized as fast, as they didn't reach a $\Delta \mathrm{pH}$ of 0.4 in $3 \mathrm{~h}$. at the optimum growth temperature. The results showed that $10 \%$ of lactobacilli were fast in the acidifying rate and $66 \%$ were slow, as they didn't reach $\Delta \mathrm{pH}$ of 0.4 after $6 \mathrm{~h}$. These results are in agreement with Durlu-Ozkaya et al., (2001) who reported that Lactobacillus strains differed in their ability to reduce the $\mathrm{pH}$ of milk initially and there were strains that didn't change the $\mathrm{pH}$ of milk after $6 \mathrm{~h}$.

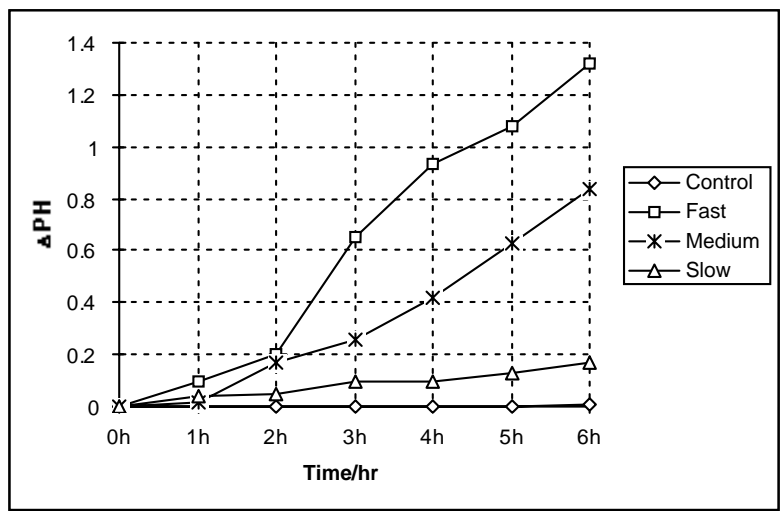

Figure 2. Acid production of different Lactococcus lactis subsp lactis strains. 
Emir. J. Agric. Sci. 2003. 15 (2): 51-71

http://www.cfs.uaeu.ac.ae/research/ejas.html

Proteolytic activity

The data reported in Figure 3 revealed the presence of active AP on leucyl paranitroanilide (Leu-PNA) as substrate for lactobacilli. Aminopeptidase activity of lactobacilli was higher when compared to lactococci and enterococci. Strain FAAU 155 can be distinguished from the other strains by its higher AP activity.

The data reported here on proteolytic activity suggested that there was no relationship between AP and acidifying activities of the strains as also suggested by Durlu-Ozkaya et al., (2001); Fortina et al., (1998). Thus strain FAAU 85 revealing good acidifying activity didn't exhibit high AP, while FAAU 115 strain with good acidifying activity showed high AP activity. Some of the cultures exhibited relatively high aminopeptidase activity. They may play a role in reducing the levels of bitterness in cheese (Ardo et al., 1989; Bartles et al., 1987 a; b; El Abboudi et al., 1991; Baankreis, 1992) and they may also play an important role in the enhancement of cheese flavour.
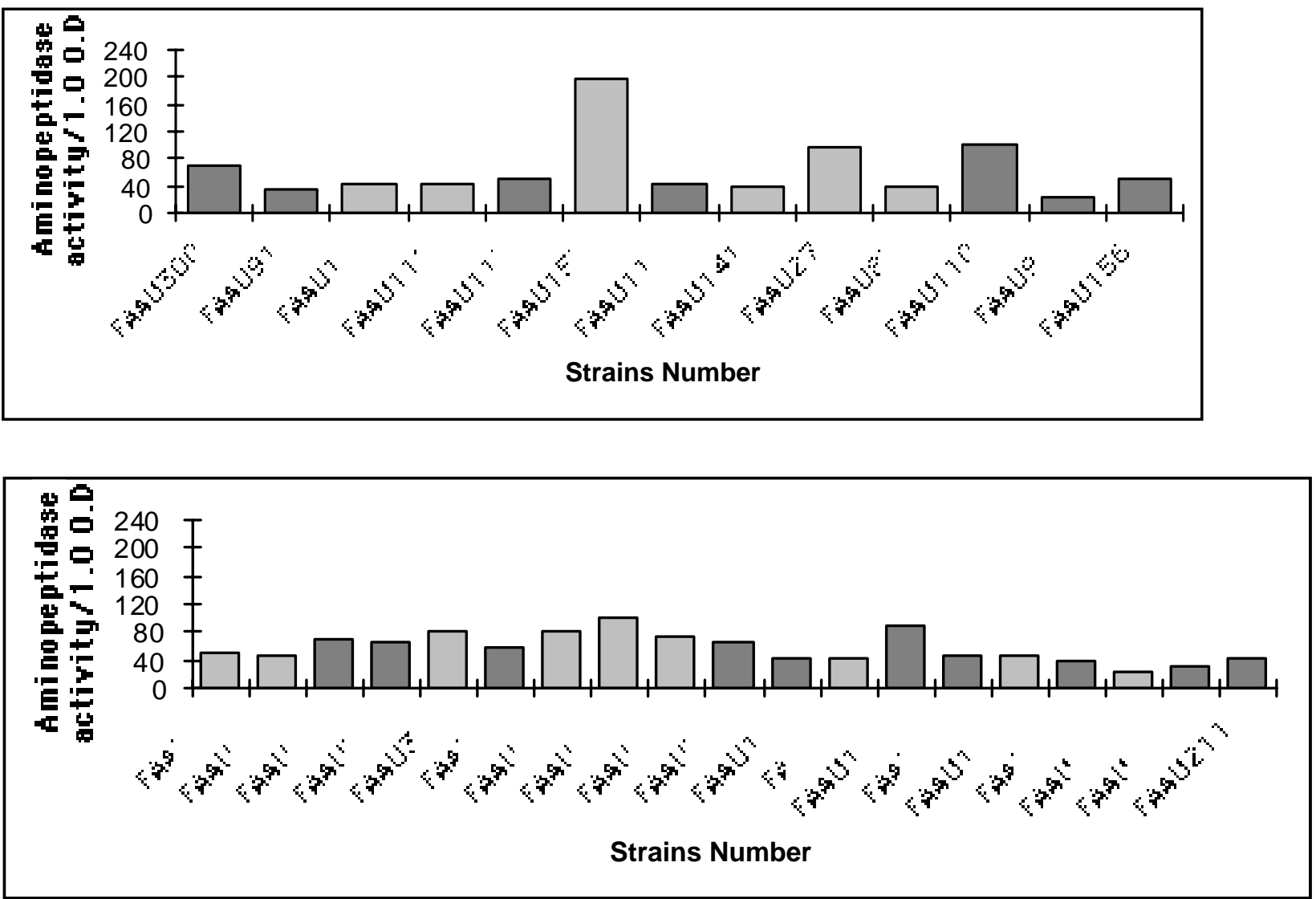

Figure 3. Aminopeptidase activity of different Lactobacillus cultures. 
Autolytic activity

Cultures were classified to their autolytic activity into 3 groups: The highly autolytic cultures L. rhamnosus FAUU110, L. paracasei subsp. paracasei FAAU27, 155 which exhibited are autolysis rate ranging from 94 to $73 \%$. The intermediate group $L$. rhamnosus FAAU23,34,55,115 showed levels of autolysis ranging from 69 to $40 \%$. The poor autolysis cultures L. rhamnosus
FAAU141, L. paracasei subsp. paracasei FAAU92 and $L$. plantarum FAAU20 showed an autolytic rate ranging from 39 to $4 \%$. Highly autolytic cultures can be of interest during cheese manufacture because of the faster release of their intercellular proteolytic and lipolytic enzymes which will contribute in flavour development during cheese ripening (E1 Soda et al., 1995, 2000b; El Soda 1997; Klein and Lortal, 1999)
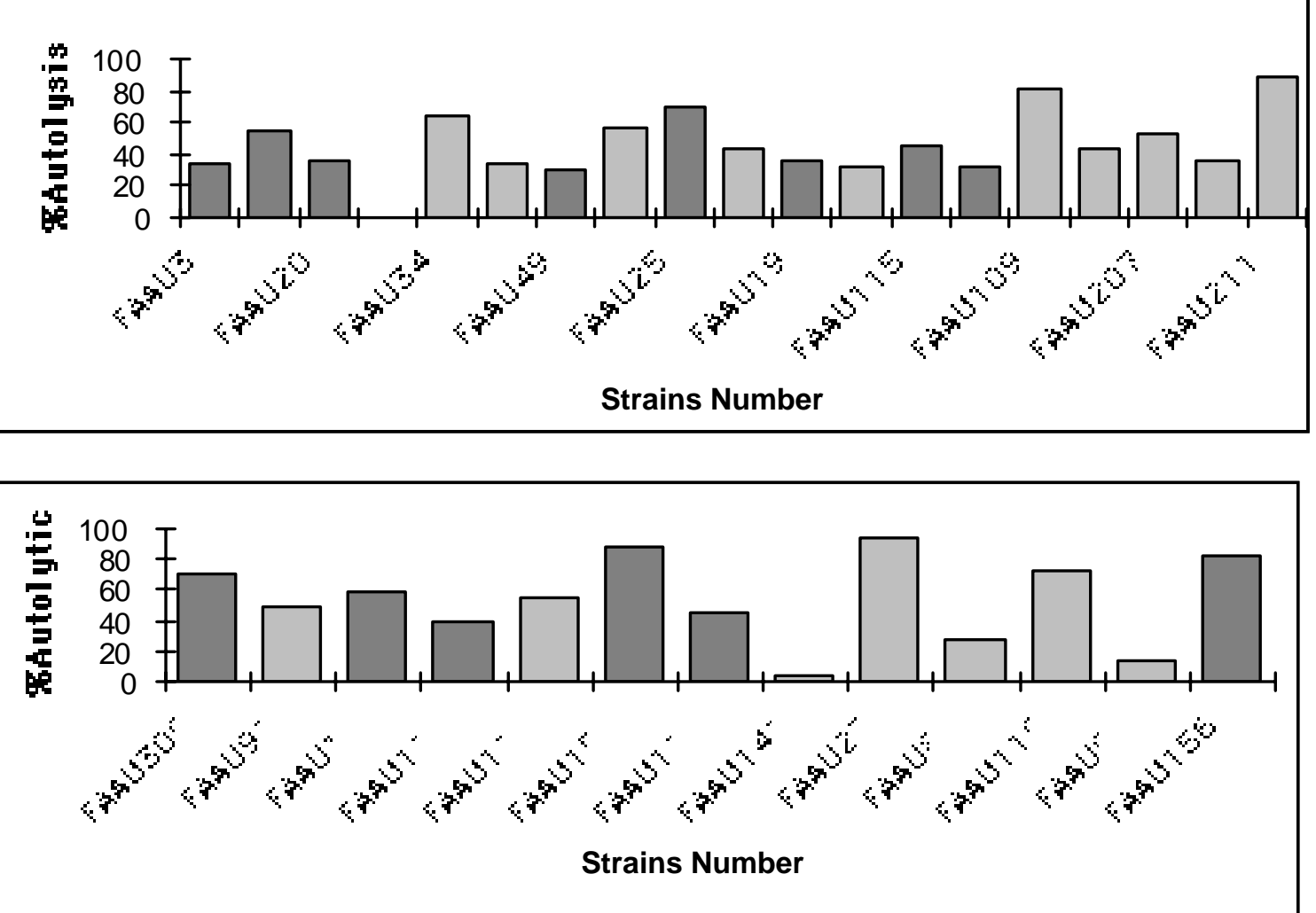

Figure 4. Autolytic activity of different Lactobacillus culture.

Exopolysaccharides (EPS) production

From Table 3 showing the ability of 190 strains to produce EPS, it appears that $26 \%$ of lactococci, $55 \%$ of enterococci, $42 \%$ of lactobacilli were able to produce EPS.
These cultures will be evaluated for their ability to improve the texture of cheese (Oberg et al., 1998) and fermented milks (Macura and Townsley, 1984; Marshall and Rawson, 1999). 
Emir. J. Agric. Sci. 2003. 15 (2): 51-71

http://www.cfs.uaeu.ac.ae/research/ejas.html

Table 3. Results of exopolysaccharides of LAB strains.

\begin{tabular}{lcc}
\hline Genus & Number of strain tested & Positive results \\
\hline Lactococcus & 62 & 16 \\
Enterococcus & 45 & 25 \\
Leuconostoc & 2 & 1 \\
Lactobacillus & 81 & 34 \\
\hline
\end{tabular}

Antagonistic activities

Seven hundred and eighty nine strains were screened for antagonistic activities. From the results, it could be noticed that none of Pediococcus, Leuconostoc and $S$. thermophilus strains showed antagonistic activity against each other. Among the Lactococcus strains, 44\% showed inhibition zons against other lactococci strains. Also, it was shown that $42 \%$ of Enterococcus strains and $23 \%$ of Lactobacillus strains showed small inhibition zones against other enterococci and lactobacilli, respectively. Most lactic acid bacterial species can produce bacteriocins which are active against the lactic acid flora itself (Piard and Desmazeaud, 1992). This work is important in the preparation of starter containing multiple strains to avoid the inhibition role of them against each other.

\section{Cheese analysis}

Gross composition

The mean composition of control (cheese without adjunct) and adjunct-treated cheeses is shown in Table (4). Gross chemical composition after four months was found to be within an average of: $\mathrm{pH}$ : $5 \pm 0.1$, Acidity \%: $2.2 \pm 0.2 \%$, Fat \%: $38 \pm 2 \%$, Moisture \%: $32 \pm 1 \%$, Protein \%: $29 \pm 2 \%$, and Salt \%: $4.5 \pm 0.2 \%$, and the means were not significantly different for all of the control and adjunct-treated cheeses.

The time required to reach the milling $\mathrm{pH}$ was almost identical in both control and cheese with added adjunct cultures. After overnight pressing, cheese made with added adjunct had lower $\mathrm{pH}$ values than did the control. This may indicate that adjunct could ferment residual lactose in cheese curd to produce lactic acid.

From these data, it can be concluded that the type of starter or adjunct did not influence the gross composition of the cheese. These results are in agreement with the data reported by Madkor et al., (2000a). 
Table 4. Gross composition of Ras cheese.

\begin{tabular}{|c|c|c|c|c|c|c|}
\hline $\begin{array}{c}\text { Starter / adjunct } \\
\text { combination }\end{array}$ & & pH & $\begin{array}{l}\% \\
\text { Fat }\end{array}$ & $\begin{array}{c}\% \\
\text { Moisture } \\
\end{array}$ & $\begin{array}{c}\% \\
\text { Protein } \\
\end{array}$ & $\begin{array}{c}\% \\
\text { Salt }\end{array}$ \\
\hline \multirow[t]{3}{*}{ Control cheese } & Zero Time & 5.20 & 32.0 & 45.0 & 17.0 & 2.5 \\
\hline & Two months & 5.12 & 38.0 & 35.0 & 22.0 & 4.2 \\
\hline & Four months & 5.06 & 40.0 & 32.0 & 22.5 & 4.7 \\
\hline \multirow[t]{3}{*}{ Adjunct Mix1 } & Zero Time & 4.98 & 33.0 & 43.5 & 18.2 & 2.6 \\
\hline & Two months & 4.95 & 39.0 & 31.6 & 22.6 & 4.6 \\
\hline & Four months & 4.88 & 40.5 & 30.5 & 23.0 & 4.9 \\
\hline \multirow[t]{3}{*}{ Adjunct Mix2 } & Zero Time & 5.04 & 33.0 & 43.2 & 17.9 & 2.5 \\
\hline & Two months & 4.96 & 39.0 & 31.9 & 21.8 & 4.4 \\
\hline & Four months & 4.94 & 40.5 & 30.6 & 22.8 & 5.1 \\
\hline \multirow[t]{3}{*}{ Commercial adjunct } & Zero Time & 5.12 & 33.0 & 43.5 & 18.1 & 2.4 \\
\hline & Two months & 5.06 & 39.5 & 31.8 & 21.9 & 4.5 \\
\hline & Four months & 4.94 & 41.0 & 30.7 & 23.1 & 5.1 \\
\hline \multirow[t]{3}{*}{ Adjunct Mix3 } & Zero Time & 5.01 & 33.5 & 43.0 & 17.7 & 2.5 \\
\hline & Two months & 4.99 & 40.5 & 32.1 & 21.6 & 4.5 \\
\hline & Four months & 4.95 & 41.0 & 30.5 & 23.3 & 5.0 \\
\hline
\end{tabular}

\section{Proteolysis}

The levels of free amino groups in cheese as measured by the Cd-ninhydrin method showed that the adjunct-treated cheese contained significantly higher concentrations of free amino groups than did control cheese by the end of ripening (Fig. 5). The significant increase in free amino group content of cheese made with adjunct may have been due to their high peptidolytic activity and high rate of cell autolysis. Thus, depending on the extent of intracellular peptidase release and the effectiveness of peptidase activities of selected adjunct added to cheese, the water-soluble peptides can be degraded rapidly to smaller peptides and elevated levels of free amino groups. Actually, enhanced autolysis and high aminopeptidase activities of adjunct can be a limiting factor in the rapid formation of flavour constituents during ripening. (El Abboudi et al., 1991; Drake et al., 1998 and Madkor et al., 2000b).

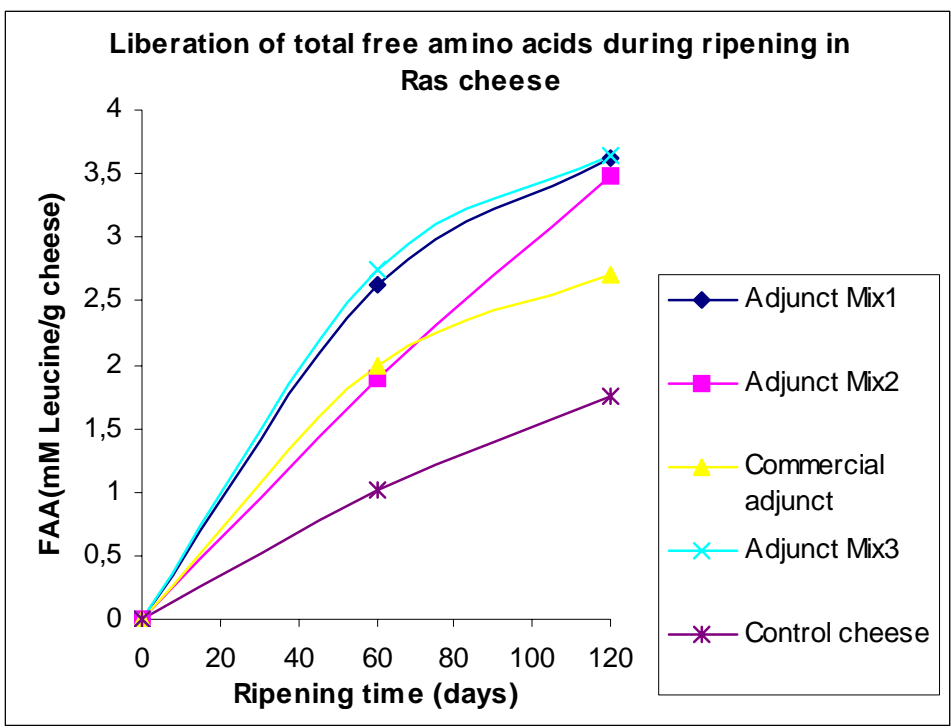

Figure 5 Evaluation of free amino acids during ripening in Ras cheese. 
Emir. J. Agric. Sci. 2003. 15 (2): 51-71

http://www.cfs.uaeu.ac.ae/research/ejas.html

\section{Lipolysis}

Lipolysis in cheese during ripening, as indicated by total free fatty acids (FFA) (measured as $\mathrm{ml}$ alcohol $\mathrm{NaOH} \mathrm{N} / 100 \mathrm{~g}$ cheese), is shown in Fig. 6. The adjuncttreated cheeses in general exhibited significantly higher levels of FFA liberation compared with control. In the progress of ripening compared with control, the total FFA increased considerably with time and was higher for all cheese at four months of ripening. Cheese made with adjunct formed the highest level of FFA compared with control cheese. These results indicated that the adjunct contributes to lipolysis in cheese, and different adjuncts have different lipolytic activity. (Khalid et al., 1990; Urtach et al., 1997; Madkor et al., 1999; Collins et al., 2003).

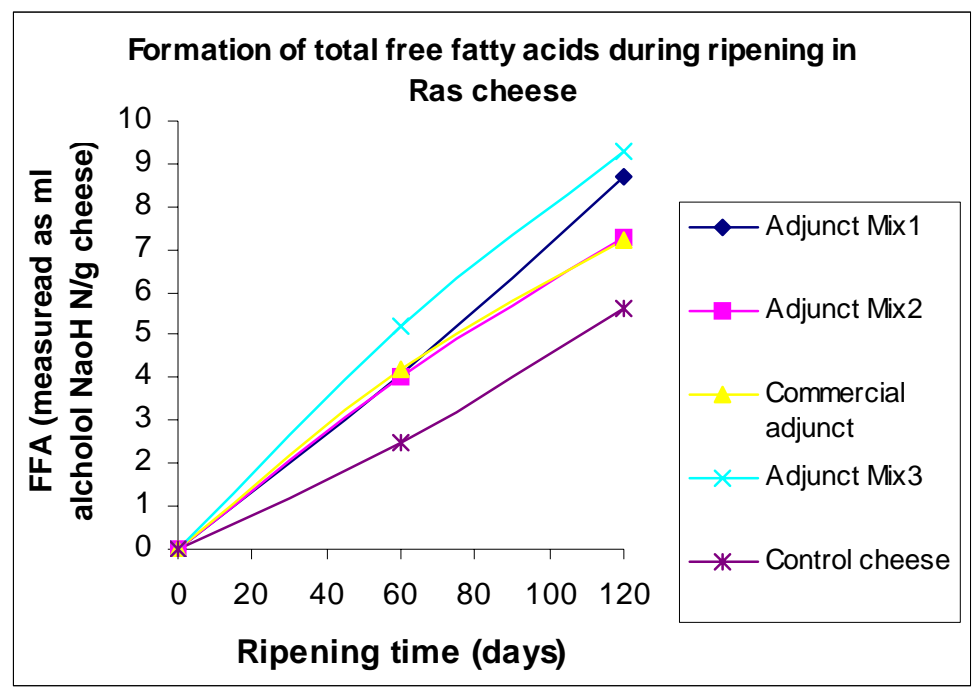

Figure 6 Evaluation of free fatty acids during ripening in Ras cheese.

\section{Sensory characteristics}

The sensory scores of cheese are summarized in Table 5. Adjunct-treated cheeses had mean organoleptic evaluation scores higher than control at each evaluation period during ripening. Other reported studies, Aly et al., (1994); Brome et al., (1990); Drake et al., (1998); Fox et al., (1998), revealed that adjunct cultures positively influenced flavour during ripening through their peptidolytic which can be linked to the high levels of free amino groups in cheese made with adjunct. Also, high FFA liberation in adjunct-treated cheeses seems to promote flavour balance. The intensity of flavour increases with time and reached its maximum after four months of ripening. Consequently, cheese maturity can be enhanced considerably depending on the type of adjunct culture used and the specific cheese-making method. (El-Soda et al., 2000a,b Katsiari et al., 2002). 
Table 5. Organoleptic evaluation of Ras cheese.

\begin{tabular}{|c|c|c|c|c|}
\hline \multirow[t]{2}{*}{ Starters } & \multicolumn{2}{|c|}{ After two months of ripening } & \multicolumn{2}{|c|}{ After four months of ripening } \\
\hline & Flavour & Texture & Flavour & Texture \\
\hline Control cheese & $\begin{array}{c}\text { Not acceptable } \\
\text { flavour }\end{array}$ & $\begin{array}{l}\text { Good } \\
\text { texture }\end{array}$ & $\begin{array}{l}\text { Not acceptable flavour, not } \\
\text { close to Ras cheese }\end{array}$ & Good texture \\
\hline Adjunct Mix 1 & Medium flavour & $\begin{array}{l}\text { Good } \\
\text { texture }\end{array}$ & $\begin{array}{l}\text { Good flavour, closer to Ras } \\
\text { than the other treatment }\end{array}$ & Good texture \\
\hline Adjunct Mix2 & Medium flavour & $\begin{array}{l}\text { Good } \\
\text { texture }\end{array}$ & Good flavour & Good texture \\
\hline $\begin{array}{l}\text { Commercial } \\
\text { adjunct }\end{array}$ & Medium flavour & $\begin{array}{l}\text { Good } \\
\text { texture }\end{array}$ & Good flavour & Good texture \\
\hline Adjunct Mix3 & Medium flavour & $\begin{array}{l}\text { Good } \\
\text { texture }\end{array}$ & $\begin{array}{l}\text { Good flavour, closer to Ras } \\
\text { than the other treatment }\end{array}$ & Good texture \\
\hline
\end{tabular}

\section{Conclusion}

The results obtained in this study revealed the presence of a wide variety of LAB in the Egyptian environments. Some of the isolated and identified LAB show outstanding performances that were similar and in some cases higher if compared to commercially available cultures, as the production of high quality cheeses requires close attention to characterization, differentiation and maintenance of starter culture strains.

A relatively high number of enterococci was detected in Egyptian dairy products; such a situation has also been reported in a wide variety of artisanal cheeses produced in southern Europe (Portugal, Spain, Italy and Greece). Enterococci have beneficial effects in cheesemaking such as hydrolysing milk fat by esterases (Tsakalidou et al., 1993) and producing typical flavour components such as acetaldehyde, acetoin and diacetyl (Centeno et al., 1996; Travalelliet et al., 1987). The cheese results indicated that maturation indices and flavour quality can be enhanced by using a combination of commercial starter culture and selected cultures isolated from the Egyptian environments, which were used as adjuncts.

\section{Acknowledgment}

The authors would like to thank the Egyptian Ministry of Agriculture and the Bureau de liaison Franco-Egyptian (BLAFE) for funding the project. Thanks to the research team involved with the project's work for their hard work and devotion.

\section{References}

Aly, M. 1994. Flavour enhancement of low fat Kashkaval cheese using heat or freezeshocked Lactobacillus delbrueckii var. helveticus cultures. Dle. Nabrug. 88: 504510 .

Ardö, T., P. Larson, L. Manson and A. Hedenberg. 1989. Studies on peptidolysis during early maturation and its influence on low fat cheese quality. Milchwissenschaft 444: 485-90.

A. O. A. C. 1960. Official methods of analysis. Association of official Analytical Chemists, Washington, D. C., U.S.A. 
Baankreis, R. 1992. The role of lactococcal peptidases in cheese ripening. $\mathrm{PhD}$ Thesis, University of Amsterdam.

Balows, A., H. Truper, M. Dvorkin, W. Harder and K. Schleifer. 1991. In: pp. 1468-1485, 1564. The Procaryotes, Vol II. New York Springer-verlag.

Bartels, H., M. Johnson and N. Olson. 1987a. Accelerated ripening of gouda cheese. I. Effect of heat- shocked thermophilic lactobacilli and streptococci on proteolysis and flavour development. Milchwissenschaft. 42: 83-8.

Bartels, H., M. Johnson and N. Olson. 1987b. Accelerated ripening of gouda cheese. II. Effect of heat shocked Lactobacillus helveticus on proteolysis and flavour development. Milchwissenschaft. 42: 139-44.

Bill, J., B. Catimel, E. Bannerman, C. Jacquet, M. N. Yersin, I. Caniaux, D. Monget and J. Rocourt. 1992. API Listeria a new and promising one-day system to identify Listeria isolates. App. Environ. Microbiol. 58: 1857-1860.

Boutrou, R., A. Sepulchre, J. C. Grippon and V. Monet. 1998. Simple tests for predicting the lytic behavior and proteolytic activity of lactococcal strains in cheese. J. Dairy Sci. 81: 2321-2328.

Brome, M. C., D. A. Krausc and M. W. Mikey. 1990. The use of starter lactobacilli in cheddar cheese manufacture. Aust. J. Dairy Technol. 45: 67-73.

Centeno, J. A., S. Menéndez and J. L. Rodriguez-Otero. 1996. Main microbial flora present as natural starters in
Cebreiro raw cow's milk cheese (Northwest Spain). Int. J. Food Microbiol. 33: 307-313.

Cerning, J. 1990. Exocellular polysaccharides produced by lactic acid bacteria. FEMS Microbiology Reviews, 87: 113-130.

Cerning, J. 1995. Production of Exopolysaccharides by lactic acid bacteria and dairy propionibacteria. Lait. 75: 463-472.

Collins, F. L. H. P. McSweeney and G. M. Wilkinson. 2003. Evidence of a relationship between autolysis of starter bacteria and lipolysis in cheddar cheese during ripening. J. Dairy Res.70: 105113.

Crescenzi, V. 1995. Microbial polysaccharides of applied interest: On going research activities in Europe. Biotechnology Progres. 11: 251-259.

De Man, J. C., M. Rogosa and M. E. Sharpe. 1960. Medium of lactobacilli. J. of Applied. Bacteriol. 23: 130-135.

Delves-Broughton, J. 1990. Nisin and its application as a food preservative. J. Soc. Dairy Technol. 43: 73-76.

Drake, M. A., T. D. Boylstem, K. D. Spendo and B. C. Swansem. 1998. Chemical and sensory effects of a lactobacillus adjunct in Cheddar cheese. Food Ites. Int. 29: 381-387.

Durlu-Ozkaya, F., V. Xanthopoulos, N. Tunail and E. Litopoulou Tsaneki. 2001. Technologically important properties of Lactic acid bacteria isolates from Beyaz 
cheese made from raw ewes milk. J. of Appl. Microbiol. 91: 861-870.

El Abboudi, M., M. El Soda, S. Pandian, M. Barreau, G. Trepanier and R. Simard. 1991. Peptidase activities in debittering and nondebittering strains of lactobacilli. Int. Dairy J. 1: 55-64.

El Soda, M. and M. J. Desmazeaud. 1982. Les peptides hydrolases des lactobacilles $\mathrm{du}$ groupe Thermobacterium I. Mise en évidence de ces activités chez Lactobacillus helveticus, L. acidophilus, L. lactis et L. bulgaricus . Can. J. Microbiol. 28 : 1181-1188.

El Soda, M., N. Farkye, J. Vuillemard, R. Simard, N. Olson, W. El Kholy, E. Dako, E. Medrano, M. Gaber and L. Lim. 1995. Autolysis of lactic acid bacteria. Impact on flavour development in cheese, In: G. Charalambous (Ed.). pp. 2205-2223. Food Flavours: Generation analysis and process influence. Elsevier Science B. v. Amstredam. The Netherlands.

El Soda, M. 1997. Control and enhancement of flavour in cheese. In: B.A. Law (Ed.). pp. 219-252. Microbiology and Biochemistry of Cheese and Fermented Milk. $2^{\text {nd }}$ ed. Blackie Academic and Professional.

El-Soda, M., S. A. Madkor and P. S. Tong. 2000a. Evaluation of commercial adjuncts for use in cheese ripening: Comparison between attenuated and not attenuated lactobacilli. Milchwissenschaft. 55: 260293.

El-Soda, M., S. A. Madkor and P. S. Tong. 2000b. Adjuncts cultures: recent developments and potential significance to the cheese industry. J. Dairy Sci. 83: 609-619.

Farrow, J. A. E. 1980. Lactose hydrolyzing enzymes in Streptococcus lactis and Streptococcus cremoris and also in some other species of Streptococci. J. of Applied Bacteriol. 49: 493-503.

Folkertsma, B. and P. F. Fox. 1992. Use of the ninhydrin reagent to assess proteolysis in cheese during ripening. J. Dairy Res. 59: 217-224.

Fortina, M. G., G. Nicastro, D. Garminati, E. Neviani and P.L. Manachini. 1998. Lactobacillus heterogeneity in natural cheese starters. The diversity in phenotypic characteristics. J. of Appl. Microbiology. 84: 72-80.

Fox, P. F., P. L. H. Mesweener and C. M. Lypcin. 1998. Non starter lactic acid bacteria in cheddar cheese. Aust. J. Dairy Technol. 53: 83-89.

Geis, E., J. Singh and M. Teuber. 1983. Potential of lactic Sterptococci to produce bacteriocin. Appl. Environ. Microbiol. 45: 205-211.

Godinho, M. and P. Fox. 1981. Ripening of Blue cheese, influence of salting rate on lipolysis and carbonyl of formation. Milchwissenschaft. 36: 476-487.

Harigon, W. F. and M. E. McCane. 1976. In: W. F. Harigon and M. E. McCane (Eds). pp. 12-15. Laboratory Methods in Foods and Dairy Microbiology. Academic Press. New York. USA.

Kamaly, K. M. and E. H. Marth. 1989. Enzymes activities of streptococci and 
their role in maturation of cheese. A. Rev. J. of Dairy Sci. 72: 1945-1966.

Kandler, O. and N. Weiss. 1986. Regular non-sporing gram-positive rods, In: P. H. A. Sneath, N. Mair, M. E. Sharpe and J. G. Hoit (Eds). pp. 1208-1234. Bergey's Manual of systematic Bacteriology 2 . Willims and Wilkins Baltimore.

Katsiari, M. C., L. P. Voutsinas and E. Kondyli. 2002. Improvement of sensory quality of lowfat Kefalograviera-type cheese by using commercial special starter cultures. J. Dairy Sci. 85: 27592767.

Khalid, N. M. and E. H. Marth. 1990. Lactobacilli their enzymes and role in ripening. J. Dairy Sci. 73: 2689-2694.

Klaenhammer, T. R. 1988. Bacteriocins of lactic acid bacteria. Biochimie. 70: 337349.

Klein, N. and S. Lortal. 1999. Attenuated starters: an efficient means to influence cheese ripening. Int. Dairy J. 9: 751-762.

Klinger, J. M., R. P. Stowe, D. C. Obenhuber, T. O. Groves, S. K. Mishra and M. D. Pierson. 1992. Evaluation of the biolog automated microbial identification system. App. Environ. Microbiol. 58: 2089-2092.

Law, B. A. and J. Kolstad. 1983. Proteolytic systems in lactic acid bacteria. Antonie an Leeuwenhoek. 49: 225-245.

Ling, E. 1952. A textbook of Dairy Chemistry. Chapman and Hall (Eds), London.
Macura, D. and P. M. Townsley. 1984. Scadinavian ropy milk- Identification of endogenous ropy lactic streptococci and their extacellular excretion. J. of Dairy Sci. 67: 735-745.

Madkor, S. A., M. El-Soda and P. S. Tong. 1999. Evaluation of commercial adjuncts for use in cheese ripening: Ripening aspects and flavour development in cheese curd slurries prepared with adjunct lactobacilli. Milchwissenschaft. 54: 134137.

Madkor, S. A., P. S. Tong and M. El-Soda. 2000a. Evaluation of commercial adjuncts for use in cheese ripening: Effect of added freeze-shocked adjunct lactobacilli on proteolysis and sensory quality of reduced fat cheddar cheese proteolysis and sensory quality of reduced fat cheddar. Milchwissenschaft. 55: 382-386.

Madkor, S. A., P. S. Tong and M. El-Soda. 2000b. Ripening of cheddar cheese with added attenuated adjunct cultures of lactobacilli. J. Dairy Sci. 82: 1684-169.

Marshall, V. and H. L. Rawson. 1999. Effects of exopolysaccharide-producing strains of thermophilic lactic acid bacteria on the texture of stirred yoghurt. International $\mathrm{J}$. of food Science and Technology. 34: 137-143.

Marugg, J. D. 1991. Bacteriocins, their role in developing natural products. Food Biotechnol. 5: 305-312.

Miozzari, G. F., P. Niederberger and R. Hutter. 1978. Permeabilization of microorganisms by Triton X-100. Analytical Biochemistry. 90: 220 - 233 . 
Oberg, C. J., J. R. Broodbent and D. J. Mc Mahon. 1998. Developments in thermophilic starter cultures for cheese. Aust. J. Dairy Technol. 53: 102-110.

Olson, N. F. 1990. The impact of lactic acid bacteria on cheese flavour. FEMS Microbiol. Rev. 87: 131-148.

Piard, J. C. and M. Desmazeaud. 1992. Inhibiting factors produced by lactic acid bacteria. 2- Bacteriocins and other antibacterial substances. Lait. 72: 113142.

Pot, B. and D. Janssens. 1993. The potential role of culture collection for identification and maintenance of lactic acid bacteria. In: Proceedings of the first lactic computer conference. The lactic acid bacteria. Horizon Scientific Press. Norfolk, U.K. p. 81-87.

Pot, B., P. Vandamme and K. Kersters. 1994. Analysis of electrophoretic whole organism protein fingerprints, In: $M$. Good fellow and A. G. O'Donnell (Eds). pp493-521. Chemical Methods in Prokaryotic Systematics. J. Wiley and Sons Limited Ltd. Chichester, NH, U.S.A.

Prescott, L. M., J. P. Harleyand and D. A. Klein. 1996. The study of microbiology structure microscopy and specimen preparation. In: pp.17-36. Microbiology. Wm. C. Brown publishers. U.S.A.

Ricciard, A. and F. Clementi. 2000. Exopolysaccharides from lactic acid bacteria: Structure, production and technological applications. Italian J. of Food Science. 1: 23-45.
Sandine, W. E. 1985. The streptococci: milk, In: S. E. Gilliland (Ed.). pp. 5-23. Bacterial starter cultures for food. Boca Raton: CRC press, Inc.

Schleifer, K. H., J. Kraus, C. Dvrak, R. Kilpper-Bälz, M. D. Collins and W. Fischer. 1985. Transfer of Streptococcus lactis and related streptococci to the genus Lactococcus. gen. nov. syst. Appl. Microbiol. 6: 183-195.

Sharpe, M. E. 1979. Identification of lactic acid bacteria, In: F. A. Skinner and D. W. Lovelock (Eds). pp233-259. Identification methods for microbiologists. London: Academic Press.

Sikkema, J. and T. Oba. 1998. Extracellular polysaccharides of lactic acid bacteria. Snow Brand R and D reports. 107: 1-31.

Speihaug, S. R. and S. K. Harlauder. 1989. Inhibition of foodborne bacterial pathogens by bacteriocins from Lactococcus lactis and Pediococcus pentosaceus. J. Food. Prot. 52: 856-862.

Stadhouders, J. 1974. Dairy starter cultures. Milchwissenschaft. 29: 329-337.

Stadhouders, J. 1986. The control of cheese starter activity. Neth. Milk Dairy J. 40: 155-173.

Thiboutot, H., E. Dako, M. El-Soda, J. C. Vuillemard, N. Power and R.E. Simard. 1995. Influence of heat freeze-shocking on the autolysis and peptidase activities of lactobacillus casei. Milchwissenschaft. 50: 448-452.

Thomas, T. D. and G. G. Pritchard.1987. Proteolytic enzymes of dairy starter 
Emir. J. Agric. Sci. 2003. 15 (2): 51-71

http://www.cfs.uaeu.ac.ae/research/ejas.html

cultures. FEMS Microbiol. Rev. 46: 245268.

Trovatelli, L. D. and A. Schiesser. 1987. Identification and significance of enterococci in hard cheese made from raw cow and sheep milk. Milchwissenschaft. 42: 717-719.

Tsakalidou, E., E. Manolopoulou, B. Tsilibari, M. Georgalaki and G.
Kalantzopoulos. 1993. Esterolytic activities from Enterococcus durans and Enterococcus faecium strains isolated from Greek cheese. Neth. Milk Dairy J. 47: 145-150.

Urtach, G. 1997. The flavour of milk and dairy products. Int. Food Technologie. 50: 79-89. 